\title{
Direction of Foreign Trade of Nepal
}

\author{
Rohit Kumar Shrestha, PhD \\ Associate Professor \\ Faculty of Management, Padma Kanya M. Campus, Kathmandu, Tribhuvan University, Nepal \\ rohitshrestha92@gmail.com \\ ORCID ID: 0000-0001-5154-1622
}

DOI: https://doi.org/10.3126/dristikon.v11i1.39156

\begin{abstract}
It is foreign trade that deals with the transaction of goods, including services, financial flows, and the movement of factors of production, like labor, capital, and entrepreneurship. The objective of the 15th plan for Nepal is to reduce the trade deficit by increasing production, managing imports, and diversifying trade on a country-wise and a goods-wise basis for export promotion and to maintain foreign exchange stability, external sector stability, and a targeted foreign exchange reserve. The purpose of this research is to assess the direction of Nepalese foreign trade. The author has not found the updated research work of the type. This is a descriptive study that uses secondary data. The analysis relies on simple mathematical tools such as ratios and percentages. The data clearly expresses a huge trade deficit. The rapidly increasing trade imbalance indicates that foreign trade policy needs to be evaluated and improved. In 2019/20, foreign trade in Nepal was adversely affected as compared to previous study years. Nepal's major trade partner is India in terms of imports, exports, trade balance, and total trade. In 2019/20, India's share of total exports stood at 71.8 percent, which was 64.6 percent last year. In total imports, India's share remained at 61.4 percent, as compared to 64.7 percent last year. The findings help the government of Nepal, researchers, practitioners, and learners to know the existing direction of foreign trade of Nepal.
\end{abstract}

Keywords: trade direction, trade deficit, foreign trade, export, import

\section{Introduction}

Countries are not self-reliant to fulfill their desires and needs by manufacturing and producing all the required goods and services. International trade means exchanging goods and services among the nations of the world (Shrestha, 2016 and Amadeo, 2021). Shrestha (2016) has stated that it is foreign trade that deals with the transaction of goods, including services, financial flows and the movement of factors of production, like labor, capital and entrepreneurship. International trade has enabled people to enjoy goods produced in other countries at reasonable prices. International trade exchanges capital goods, raw materials, and transfers technological know-how. Total trade equals exports plus imports. According to Amadeo (2021), total 
international trade in 2019 was just under $\$ 19$ trillion. Goods and services from one country to another country and one place to another place at a reasonable price, due to the development of modern transportation and communication, has become possible.

Globalization has made international trade even easier. Nepal's international trade was limited only to Tibet and India during the Lichchhavi and Malla eras, as well as to the Rana regime. Following the Rana era, international trade with Nepal expanded to many other countries around the world. Since the 1970s, the balance of trade has been increasingly negative.

\section{Theoretical Perspective of International Trade}

The absolute advantage theory has been developed based on the principle of division of labor and a free trade system. The theory's main argument was that if a country gains absolute cost advantages for one product while suffering disadvantages for another, it will have an advantage over other countries. Countries may export and import commodities based on cost advantage and cost disadvantage and enjoy the profit. This can boost world output without an increase in the cost of production.

The comparative advantage theory has been explained by Ricardo as being due to differences in labor productivity. All countries have a comparative advantage in something. However, no country can have a comparative advantage in everything. Suppose that it takes a minimum time of labor to produce something in the home country, while it may take a maximum time of labor to produce the same thing in a foreign country.

The opportunity cost theory was developed by GotterfriedHaberler in 1993. Opportunity cost means the rate at which one product is being given up to receive a certain quantity of another product. The theory notes that the cost of a product is the amount of another product that must be sacrificed to release just enough factors of production or resources to be able to produce one additional unit of the first commodity (Ghimire, 2010)

The Heckscher-Ohlin theory says that a nation specializes in the manufacturing and production and export of products whose goods need a comparatively large number of the factors with which the nation is comparatively well capable.

\section{Policy Overview of Nepalese Trade}

The vision of Trade Policy 2015 is to achieve economic prosperity by enhancing the trade sector's contribution to the national economy through export promotion. The strategies focus on strengthening supply-side capacity, increasing exports of value-added competitive products and services to the world market, increasing access to goods, services, and intellectual property to regional and world markets, among others. The Board includes the private sector and has the 
responsibility of assisting in formulating policies necessary for trade promotion, trade facilitation, policy monitoring, and interagency coordination.

According to Nepal Rastra Bank 2020, the Industrial Policy 2010 directs the industrial sector of Nepal. Its objectives were to enhance the export of industrial goods, improve the industrial sector's contribution to the economy by using local resources, make industrial enterprises sustainable and dependable through the application of innovative and environmentfriendly technology, make Nepal an attractive destination in South Asia for investment, and protect the intellectual property rights of industries. The Industrial Policy, 2010 was supported by the Industrial Enterprises Act, 2016, which replaced the Industrial Enterprises Act, 1992.

It believes in maintaining amicable and mutually beneficial trade relations with its neighboring countries, China and India, which are its largest trading partners. Nepal and India share open borders and have a multi-dimensional friendly relationship in various economic spheres, with trade and transit being core elements. India is not only Nepal's largest trading partner with almost two-thirds of the share in Nepal's total trade but also the largest market for Nepali goods.

Nepal has joined two regional agreements - the South Asian Free Trade Area (SAFTA) and the Bay of Bengal Initiative for Multi-Sectoral, Technical and Economic Cooperation (BIMSTEC). While SAFTA focuses on the South Asian region, BIMSTEC connects South Asia with South East Asia.

The SAFTA Agreement, which succeeded the South Asian Preferential Trade Agreement (SAPTA), was signed in 2004 and came into force in 2006. It aims to deepen trade and economic cooperation among member countries by promoting fair competition through the removal of barriers to facilitate cross-border movements of goods. The sixth meeting of the SAFTA Council in 2012 took the initiative to reduce the number of products on the sensitive lists by 20\%; Nepal has already achieved the relevant target by 2014 .

BIMSTEC was founded in 1997 to accelerate growth through cooperation in various areas of shared interest. Nepal joined BIMSTEC in 2004, the year in which a framework agreement with provisions for liberalizing trade in goods and services and negotiating an agreement related to cross-border investment facilitation was also signed. In 2016, BIMSTEC came up with the Outcome Document and the 16-point Agenda of Action, highlighting the priority actions to be implemented. Recent meetings have seen members re-affirm their commitments to agreements in various sectors. Energy cooperation has been a key feature of the BIMSTEC agenda. The process of negotiations on reducing and eliminating tariffs is underway.

Nepal has been playing a significant role in giving momentum to BIMSTEC and is hosting BIMSTEC Summit, the highest policymaking body in BIMSTEC. Nepal is a strong 
supporter of the Multilateral Trading System (MTS) and believes in a rule-based, transparent, and predictable MTS. Despite various constraints, Nepal has participated actively in the WTO and has consistently met its obligations since its accession in 2004.

\section{Periodic Plan and Trade Policy}

The goal of the $14^{\text {th }}$ plan was to maintain a surplus balance of payment and to reserve foreign exchange through export promotion, import-substitution, tourism promotion, energy development, the attraction of foreign investment and remittance mobilization. Similarly, the plan's goal was to rapidly reduce the trade deficit by performing internal production of potential commodities and country- and commodity-wise diversification of the plan was to expand and diversify the country-wise and goods-wise export market by increasing production of goods and services and to replace imports by producing currently imported goods and services (National Planning Commission, 2015)

The vision of the National Planning Commission's 15th plan is a strengthened economy with balanced foreign trade, adequate foreign exchange reserves, and external sector stability of the plan is to promote exports, balance foreign trade, and maintain a surplus balance of payment. Similarly, the objectives of the plan are to reduce the trade deficit by increasing production, managing imports, and diversifying trade on a country-wise and a goods-wise basis for export promotion and to maintain foreign exchange stability, external sector stability, and a targeted foreign exchange reserve. The plan's strategy is to develop and increase the production of sectors with comparative advantages such as agriculture, herbs, hydroelectricity, and tourism; manage imports by controlling unnecessary imports, and increase the production of goods and services. This plan will be centered on maintaining the necessary foreign exchange reserves to support imports of goods and services, as well as achieving a positive balance of payment status by reducing the trade deficit (National Planning Commission, 2020).

The working policies of the plan were the production of agricultural and industrial goods such as pulses, oilseeds, fruits, shoes, cement, garments, and iron promoted. The imports of petroleum products, gas, and coal will be reduced by increasing electricity production and providing concessions for using electronic equipment. Legal provisions will be made to discourage the import of low-quality and unnecessary goods and services. Policies related to foreign trade will be updated.

\section{Statement of the Problems}

The main reasons for Nepal's massive trade deficit are low exports and high imports, the country's landlocked status, low-quality goods, poor trade policy, inefficiency, slow industrial development, a lack of country- and product-specific trade diversification, a lack of publicity, and advertising, and so on. Nepal has a substantial gap between its objectives and vision and the current state of affairs in the trade sector (Ghimire, 2010). Nepal has not yet 
properly developed the institutional and legal structures to implement the World Trade Organization agreement. Nepal has yet to reap the full benefits of globalization, which has presented both opportunities and challenges to countries, regions, and peoples all over the world. These are the main problems of Nepal's foreign trade and trade imbalance. Until and unless Nepal increases its trade competitiveness by adopting different policies, it cannot reduce its ever-increasing trade deficit.

\section{The Research Questions}

The following research questions have been set:

- What is the direction of the foreign trade of Nepal?

- How does the direction of the foreign trade move in Nepal?

\section{The Objective of the Study}

The extent economic of the growth in any country depends upon foreign trade. The objective of the study is to assess the direction of the foreign trade. It also analyses the process of the movement of the international trader.

\section{Research Gap}

The author has not found the updated research work of the type to assess the overall direction of the foreign trade of Nepal. So, the author is conscious of the novelty and relevancy of the study.

\section{Significance of the Study}

Foreign trade that deals with the transaction of goods, including services, financial flows are devised and carried out across national borders to satisfy the objectives of individuals, companies, and the nation. The economic development of the country is more likely to depend on international trade. It has a strong positive impact on the Gross Domestic Product of the nation. However, Nepal is facing a tremendous trade deficit. The study helps to assess the causes of the massive problem i. e. trade deficit and find the solution to the problem. The most effective technique to solve and address the trade deficit is to increase exports. Nepal must be able to diversify its foreign trade in terms of countries and commodities immediately. Trade policies of Nepal should be formulated considering new external as well as internal environments.

\section{Limitation of the Study}

The study has suffered some limitations; a short literature review, based on secondary data collected from an overall annual report. The application of only ratios and percentages in analyzing the data is another limitation of this study. 


\section{Review of Literature}

The large disparity between imports and exports in the country is causing a massive trade deficit and putting the economy under international exchange pressure (Sharma \& Bhandari, 2005; Ghimire, 2010; Shrestha, 2016; Acharya, 2019). Besides this, Nepal is facing many challenges and difficulties in the trading of goods and services (Mahat, 2015). Sharma and Bhandari (2005) discovered that export growth led to the economic growth of Nepal. Nepal's foreign trade has been suffering from a deficit, which could hurt the foreign currency reserve of the country. The government should encourage a policy of adequate investment in exportoriented industries that embodies a 'proper mix' of export promotion and import substitutions.

Acharya (2019), in his article, "Nepalese Foreign Trade: Growth, Composition, and Direction" concluded that because of low export performance, Nepal was facing the problem of a rapidly increasing trade deficit. The main reasons for Nepal's massive trade deficit are low exports and high imports, the country's landlocked status, low-quality goods, poor trade policy, low production, slow industrial development, a lack of trade diversification, higher production costs, a lack of publicity and advertising, and so on. Until and unless Nepal increases its trade competitiveness by adopting different policies, it cannot reduce its ever-increasing trade deficit.

The United Nations (2021) on "Key Statics and Trends in International Trade 2020" stated that COVID-19 negatively and strongly impacted international trade in 2020. Most of the world's major economies experienced the steepest drops in April and May of 2020. World trade is largely unbalanced. Primarily, the United States runs a large trade deficit. Similarly, many developing and developed countries are experiencing trade deficits. Even though these imbalances are sometimes large, they often tend to be low relative to the country's GDP.

Ghimire's (2010) research study concluded that foreign trade in Nepal has been facing a widening trade deficit i.e., a heavy increase in imports and declining exports. Nepal's trade heavily depends on India, both for imports and exports. Nepal has to increase its capacity to gain from liberalization and integration with the sub-region and the world economy. This trade deficit necessitates a rethinking and reforming of foreign trade policy. The effective treatment of the trade deficit is to boost our exports.

Ghimire (2010) focused that the causes of the interrelationships and interdependence between and among countries are economic and technological development. Developing countries are considered as weaker partners in the world market. Nepal has a big gap between its objectives and vision and the current state of affairs in the trade sector. Market and product diversification of exports is required. Nepal has not yet properly developed the institutional and legal structures to implement the WTO agreement. Nepal has not yet received the full benefits of globalization that have presented both opportunities and challenges to countries, regions, and peoples in the globe. 
Shrestha's (2016) finding titled "Foreign Trade Situation of Nepal" analyzed the growth, direction and trade balance of Nepal's foreign trade for the period 2005/6 to 2014/15. The study discovered that imports grew rapidly (at an annual average rate of 17\%) while exports grew slowly (at an annual rate of $4 \%$ ) during the study period. As a result, the trade balance is negative and is growing every year. Such a trend cannot be sustained for an extended period. Furthermore, Nepal's foreign trade is overly reliant on India (exceeding two-thirds of both exports and imports), and it needs to diversify into the rest of the world.

\section{Materials and Methods}

The study was based on secondary data collected from an annual report published by the Nepal Rastra Bank. The study was descriptive in nature. The study period was six fiscal years, i.e., from 2014/15 to 2019/20. To examine the pattern of foreign trade and trade balances, annual growth rates, export to import ratio, share of total exports and imports, share of trade balance, and share of total trade have been calculated. The research is based on quantitative data. The description of Nepalese foreign trade and trade performance is entirely based on quantitative data. Ratios and percentages were used to analyze the data.

\section{Results and Discussion}

Table 1 presents Nepal's total export, total import, total trade balance and total foreign trade and their percent change data for a period of 3 years i.e., from the Fiscal Year 2014/15 to 2016/17.

\section{Table 1}

The direction of Export, Import, Trade Balance and Foreign Trade of Nepal

\begin{tabular}{lrrrrl} 
& & & \multicolumn{2}{c}{ (Rs. in Million) } \\
\hline & $2014 / 15$ & $2015 / 16$ & $2016 / 17$ & $2015 / 16$ & $2016 / 17$ \\
\hline Total Exports & 85319.1 & 70117.1 & 73049.1 & -17.8 & 4.2 \\
To India & 55864.6 & 39493.7 & 41449.2 & -29.3 & 5.0 \\
To China & 2229.9 & 1681.5 & 1701.5 & -24.6 & 1.2 \\
To Other countries & 27224.6 & 28941.9 & 29898.4 & 6.3 & 3.3 \\
& & & & & \\
Total Imports & 774684.2 & 773599.1 & 990113.2 & -0.1 & 28 \\
From India & 491655.9 & 477212.6 & 633669.6 & -2.9 & 32.8 \\
From China & 100166.4 & 115694.3 & 127245.0 & 15.5 & 10 \\
From Other Countries & 182861.9 & 180692.2 & 229198.6 & -1.2 & 26.8
\end{tabular}


DRISTIKON, VOL. 11(1), 155-168, 2021, RMC, MMC, DHARAN

Total Trade Balance

With India

With China

With other countries

Total Foreign Trade

With India

With China

With Other Countries

$\begin{array}{cc}-689365.1 & -703482.2 \\ -435791.3 & -437718.9 \\ -97936.5 & -114012.8 \\ -155637.3 & -151750.3 \\ & \\ 860003.3 & 843716.3 \\ 547520.5 & 516706.3 \\ 102396.3 & 117375.8 \\ 210086.5 & 209634.1\end{array}$

$-917064$

2.0 $-592220.4$

0.4

16.4

$-2.5$

30.4

$-125543.5$

$-199300.2$

$-1.9 \quad 26.0$

$-5.6 \quad 30.7$

$14.6 \quad 9.9$

$-0.2 \quad 23.6$

Table 2 presents Nepal's total exports, total imports, total trade balance and total foreign trade and their percent change data for a period of 3 years, i.e., from the Fiscal Year $2017 / 18$ to $2019 / 20$.

Table 2

The direction of Export, Import, Trade Balance and Foreign Trade of Nepal

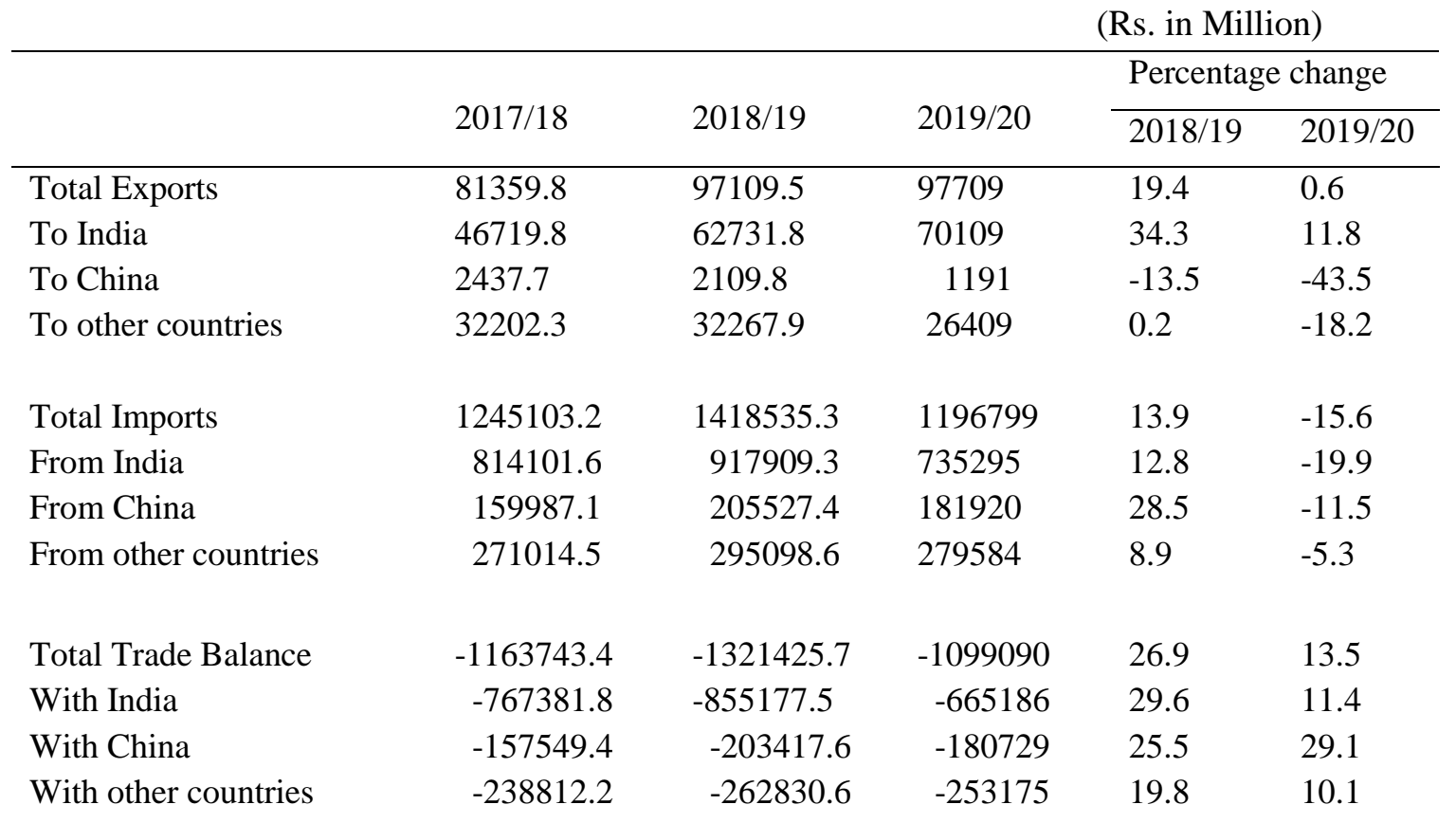


DRISTIKON, VOL. 11(1), 155-168, 2021, RMC, MMC, DHARAN

\begin{tabular}{lccrrc} 
Total Foreign Trade & 1326463 & 1515644.8 & 129450.8 & 14.3 & -14.6 \\
With India & 860821.4 & 980641.1 & 80540.4 & 13.9 & -17.9 \\
With China & 162424.8 & 207637.2 & 18311.1 & 27.8 & -11.8 \\
With Other Countries & 303216.8 & 327366.5 & 30599.3 & 8.0 & -6.5 \\
& & & & & \\
\hline
\end{tabular}

Table 1 shows that total merchandise exports decreased by 17.8 percent to Rs. 70117.1 million in 2015/16. Exports of this type increased by 4.2 percent in 2016/17. Out of total merchandise exports, exports to India decreased by 29.3 percent to Rs.39493.7 million in 2015/16 compared to an increase of 5 percent in the upcoming year of 2016/17. Exports to China declined by 24.6 percent in 2015/16, compared to an increase of 1.2 percent (from Rs. 1681.5 million to Rs. 1701.5 million) in 2016/17. Likewise, exports to other countries increased by 6.3 percent in 2015/16. It increased by 3.3 percent in 2016/17.

In 2015/16, total merchandise imports decreased by 0.1 percent to Rs. 773599.1 million. Such imports have increased by 28 percent to Rs. 990113.2 million in 2016/17 compared to $2015 / 16$. Imports from India have decreased by 2.9 percent in $2015 / 16$. These imports increased by 32.8 percent in 2016/17 compared to the previous year. Imports from China increased by 15.5 percent to Rs. 115694.3 million in 2015/16. Such imports increased by 10 percent (from Rs. 115694.3 million to Rs. 127245.0 million) in 2016/17. Imports from other countries decreased by 1.2 percent in the Fiscal Year 2015/16. Such imports increased by 26.8 percent in 2016/17 as compared to 2015/16. The trade deficit increased by 2 percent to Rs. 703482.2 million in 2015/16. In 2016/27, the deficit has increased by 30.4 percent compared to 2015/16.

Table 2 shows that total merchandise exports increased by 19.4 percent to Rs. 97109.1 million in 2018/19. Exports of this type increased by 11.4 percent last year and by 0.6 percent in 2019/20. Out of total merchandise exports, exports to India increased by 34.3 percent to Rs.62731.8 million in 2018/19 compared to an increase of 12.7 percent in previous year and 11.8 percent in upcoming year of 2019/20. Exports to China declined by 13.5 percent in 2018/19, compared to an increase of 43.3 percent in the previous year and a decrease of 43.5 percent (from Rs. 2109.8 million to Rs. 1191 million) in 2019/20. Likewise, exports to other countries increased by 0.2 percent compared to an increase of 7.7 percent in the previous year. It decreased by 18.2 percent in 2019/20.

In 2018/19, total merchandise imports increased by 13.9 percent to Rs. 1418535.3 million. Such imports have increased by 25.8 percent from the previous year. It, however, decreased by 15.6 percent (from Rs. 1418535.3 million to Rs. 1196799 million) in 2019/20 as compared to 2018/19. Imports from India have increased by 12.8 percent. Such imports have increased by 28.5 percent from the previous year. These imports declined by 19.9 percent in 2019/20 compared to the previous year. In the fiscal year, imports from China increased by 
28.5 percent to Rs. 205527.4 million as compared to an increase of 25.7 percent in the previous year. Such imports decreased by 11.5 percent (from Rs. 205527.4 million to Rs. 181920 million) in 2019/20. Imports from other countries increased by 8.9 percent in Fiscal Year 2018/19, compared to an increase of 18.2 percent the previous year. Such imports decreased by 5.3 percent in $2019 / 20$ as compared to $2018 / 19$. The trade deficit increased by 26.9 percent to Rs. 1321425.7 million in 2018/19. In 2019/20, the deficit has increased by 13.5 percent when compared to $2018 / 19$.

Table 3 shows the exports to imports ratio, share in total exports, share in total imports, share in trade balance, and share in total trade for India, China, and other countries, as well as the share of exports and imports in Total Trade.

Table 3

Import, Export \& Trade Balance ratio

\begin{tabular}{|c|c|c|c|c|c|c|}
\hline Fiscal Year & $2014 / 15$ & $2015 / 16$ & $2016 / 17$ & $2017 / 18$ & $2018 / 19$ & $2019 / 20$ \\
\hline 1 Ratio of Exports to Imports: & 11 & 9.1 & 7.4 & 6.5 & 6.8 & 8.2 \\
\hline India & 11.4 & 8.3 & 6.5 & 5.7 & 6.8 & 9.5 \\
\hline China & 2.2 & 1.5 & 1.3 & 1.5 & 1 & 0.7 \\
\hline Other Countries & 14.9 & 16 & 13.0 & 11.9 & 10.9 & 9.4 \\
\hline \multicolumn{7}{|l|}{2 Share in Total Exports: } \\
\hline India & 65.5 & 56.3 & 56.7 & 57.4 & 64.6 & 71.8 \\
\hline China & 2.6 & 2.4 & 2.3 & 3 & 2.2 & 1.2 \\
\hline Other Countries & 31.9 & 41.3 & 40.9 & 39.6 & 33.2 & 27.0 \\
\hline \multicolumn{7}{|l|}{3 Share in Total Imports: } \\
\hline India & 63.5 & 61.7 & 64.0 & 65.4 & 64.7 & 61.4 \\
\hline China & 12.9 & 15 & 12.9 & 12.8 & 14.5 & 15.2 \\
\hline Other Countries & 23.6 & 23.4 & 23.1 & 21.8 & 20.8 & 23.4 \\
\hline \multicolumn{7}{|l|}{3 Share in Trade Balance } \\
\hline India & 63.2 & 62.2 & 64.0 & 65.9 & 64.7 & 60.5 \\
\hline China & 14.2 & 16.2 & 13.7 & 13.5 & 15.4 & 16.4 \\
\hline Other Countries & 22.6 & 21.6 & 21.7 & 20.5 & 19.9 & 23 \\
\hline \multicolumn{7}{|l|}{ 4Share in Total Trade } \\
\hline India & 63.7 & 61.2 & 63.5 & 64.9 & 64.7 & 62.2 \\
\hline China & 11.9 & 13.9 & 12.1 & 12.2 & 13.7 & 14.1 \\
\hline Other Countries & 24.4 & 24.8 & 24.4 & 22.9 & 21.6 & 23.6 \\
\hline \multicolumn{7}{|l|}{$\begin{array}{l}\text { 5Share of Exports \& Imports in } \\
\text { Total Trade }\end{array}$} \\
\hline Export & 9.9 & 8.3 & 6.9 & 6.1 & 6.4 & 7.5 \\
\hline Import & 90.1 & 91.7 & 93.1 & 93.9 & 93.6 & 92.5 \\
\hline
\end{tabular}


Note. Annual Report, Nepal Rashtra Bank.

Tables 1, 2, and 3 show the direction of Nepalese foreign trade from the fiscal year $2014 / 15$ to the fiscal year 2019/20. From the tables, it is clear that Nepal's major trade partner is India. About two-thirds of Nepal's total trade is with India. Table 3 shows that the exportimport ratio increased to 8.2 percent in 2019/20. Last year, the ratio was 6.8 percent. The ratios were 6.5 percent, 7.4 percent, 9.1 percent and 11.4 percent in 2017/18, 2016/17, 2015/16 and $2014 / 15$ respectively. India's share of total exports stood at 71.8 percent, which was 64.6 percent, 57.4 percent, 56.7 percent, 56.3 percent, and 65.5 percent in 2018/19, 2017/18, 2016/17, 2015/16 and 2014/15 respectively. In total imports, India's share remained at 61.4 percent as compared to 64.7 percent last year. India's share of the trade deficit and total trade remained at 60.5 percent and 62.2 percent in 2019/20, which was 64.7 percent and 64.7 percent last year. Similarly, the share of exports \& imports in total trade remained at 7.5 percent and 92.5 percent in 2019/20. The shares of the same were 6.4 percent and 93.6 percent, 6.1 percent and 93.9 percent, 6.9 percent and 93.1 percent, 8.3 percent and 91.7 percent and 9.9 percent and 90.1 percent in 2018/19,2017/18, 2016/17, 2015/16 and 2014/15 respectively.

\section{Findings}

The study discovers that while imports have grown rapidly, exports have grown at a very slow pace over the study period, i.e. from 2014/15 to 2019/20. The average share of total trade in exports and imports remained at 7.5 percent and 92.5 percent, respectively. This is creating the problem of a rapidly increasing trade deficit. There is also a big gap between vision, mission, goals and objectives and the actual state of affairs in the trade sector. The rapidly increasing trade imbalance indicates that foreign trade policy needs to be evaluated and improved. Data clearly indicates that foreign trade in Nepal was adversely affected in 2019/20 as compared to previous study years. Total merchandise exports increased by only 06 percent. Similarly, total merchandise imports decreased by 15.6 percent as compared to last year. Imports of this type increased by 13.9 percent in the previous year. Total foreign trade decreased by 14.5 percent as compared to last year.

It is clear that Nepal's major trade partner is India in terms of imports, exports, trade balance and total trade. In 2019/20, India's share of total exports stood at 71.8 percent, which was 64.6 percent last year. In total imports, India's share remained at 61.4 percent, as compared to 64.7 percent last year. The most effective technique to address the trade deficit is to increase exports. Nepal must be able to diversify its foreign trade in terms of countries and commodities immediately. Trade policies of Nepal should be formulated considering the new external as well as internal environments. The major causes of an increasing trade deficit are improper trade policy due to political instability, open-door policy, low exports, and high imports, lowquality products, lack of enough technologies, and higher cost of production, low production of 
agricultural and industrial products, and lack of country-wise and product-wise diversification for export promotion. This finding is similar to the studies of Ghimire, 2010; Mahat, 2015, and Shrestha, 2016 who concluded the large disparity between imports and exports in the country is causing a massive trade deficit and putting the economy under international exchange pressure. The studies also revealed that Nepal has been facing many challenges and difficulties in the trading of goods and services.

\section{Conclusion}

Because of low export performance, Nepal is facing a tremendous trade deficit. There is also a big gap between vision, mission, goals and objectives, and the actual state of affairs in the trade sector. The rapidly increasing trade deficit indicates that foreign trade policy should be evaluated and improved to reflect the present environment. The most effective technique to address the trade deficit is to increase exports. The facts explicitly show that foreign trade in Nepal was adversely affected in 2019/20 compared to previous years. Nepal must be able to diversify its foreign trade in terms of countries and commodities immediately. It is clear that Nepal excessively depends on India in terms of imports, exports, trade balance, and total trade. In 2019/20, India's share of total exports stood at 71.8 percent, which was 64.6 percent last year. In total imports, India's share remained at 61.4 percent, as compared to 64.7 percent last year. The major causes of Nepal's increasing trade deficit are low exports and high imports, a landlocked country, low-quality goods, improper trade policy, higher cost of production, lack of publicity and advertisement, low production, slow industrial development, lack of countrywise and product-wise diversification for export promotion, etc. Until and unless Nepal increases its trade competitiveness by adopting different policies, it can't reduce its everincreasing trade deficit.

\section{Implications}

First, the findings help the government of Nepal to know the existing direction of foreign trade of Nepal. The rapidly increasing trade imbalance indicates that foreign trade policy needs to be evaluated and improved. In 2019/20, foreign trade in Nepal is adversely affected as compared to previous study years. The major causes of Nepal's increasing trade deficit are low exports and high imports, a landlocked country, low-quality goods, improper trade policy, slow industrial development, lack of country-wise and product-wise diversification for export promotion, and so on. The most effective technique to address the trade deficit is to increase exports. Nepal must be able to diversify its foreign trade in terms of countries and commodities immediately. Trade policies of Nepal should be formulated considering new external as well as internal environments. From the theoretical point of view, the study provides a valuable contribution in the field of literature. A better understanding of the status of Nepalese foreign trade can address the gaps currently existing in the literature. This study may help the 
researchers, practitioners, and students to improve knowledge and idea. The study has academic implications too because this type of study will provide knowledge from an academic perspective such as in the field of management and business too.

\section{References}

Acharya, K. R. (2019). Nepalese Foreign Trade: Growth, Composition, and Direction. NCC Journal, 4(1).

Amadeo, K. (2021). International Trade: Pros, Cons, and Effect on the Economy. Retrieved fromhttps://www.thebalance.com/international-trade-pros-cons-effect-on-economy3305579

Bashyal, R. (2008). Nepal Trade Expansion among SAARC Countries and Regional Trading Arrangement. Kathmandu: Nepal Rastra Bank.

Ghimire, R. (2010). Direction of foreign trade. Journal of Finance and Management Review, 1(2), 1-11, Retrieved from https://www.academia.edu/5590497/

Mahat, B. (2015). Impact of Trade Deficit in Nepalese Economy: Deficit in Merchandise Trade.

Ministry of Industry, Commerce and Supplies (2018). Nepal Trade Policy Review-2018.

Retrieved from

https://moics.gov.np/uploads/shares/policy/Trade\%20Policy\%20Review\%20201

National planning commission. (2018). The Fourteenth Plan Fiscal Year (2073/74-

2075/76). Kathmandu: National Planning Commission-Kathmandu.

National planning commission (2020). The Fifteenth Plan (Fiscal Year 2019/20-2023/24).

Kathmandu: National Planning Commission-Kathmandu.

Nepal Rastra Bank. (2015). Annual Report. Kathmandu: Nepal Rastra Bank.

Nepal Rastra Bank. (2017). Annual Report.Kathmaudu: Nepal Rastra Bank.

Nepal Rastra Bank. (2020). Annual Report. Kathmandu: Nepal Rastra Bank.

Pant, B. (1994). Trade and development: Nepal's experience. New Delhi: Oxford and IBH Publishing Cooperative Private Limited

Sharma, O. \& Bhandari, R. (2005). Foreign Trade and Its Effects on Nepalese Economic

Development.The Journal of Nepalese Business Studies, 2 (1), 13-32.

Shrestha S. S. (2016). Foreign trade situation of Nepal.PYC Journal of Management, 9(1), 78-82. 
United Nations. (2021). Key statics and trends in international trade 2020. United Nations, New York, United State.

Upreti, S.K.(2012).Openness and Trade: Some Empirical Evidences from Nepalese International Trade.Pravaha: A Journal of Management, 18(18). 